\title{
Contribution of airborne dust particles to HONO sources
}

\section{N. A. Saliba ${ }^{1}$, S. G. Moussa ${ }^{2}$, and G. El Tayyar ${ }^{1}$}

${ }^{1}$ American University of Beirut, Department of Chemistry, Beirut, Lebanon

${ }^{2}$ Air Quality Research Section, Environment Canada, 4905 Dufferin Street, Toronto, Ontario, M3H 5T4, Canada

Received: 9 January 2014 - Accepted: 31 January 2014 - Published: 21 February 2014

Correspondence to: N. A. Saliba (ns30@aub.edu.lb)

Published by Copernicus Publications on behalf of the European Geosciences Union.

\section{Contribution of airborne dust particles to HONO \\ sources \\ N. A. Saliba et al.}

\section{Title Page}

Abstract

Conclusions

Tables

14

Back 


\section{Abstract}

$\mathrm{HONO}$ is a major precursor for $\mathrm{OH}$ radicals in early mornings. Its formation has been mainly attributed to the heterogeneous hydrolysis of $\mathrm{NO}_{2}$ on surfaces such as soot, glass, mineral oxides and aerosol surfaces. In particular, dust events which are loaded 5 with mineral oxide aerosols have been associated with higher HONO concentrations in the gas phase. In order to understand the mechanism of reactions related to this process, samples during dusty and non-dusty days were collected between October 2009 and April 2011. Based on HYSPLIT backward trajectories, data were divided between wind trajectories originating from Arabian or African deserts. In this study an increase f centrations was accompanied by an increase in the PM nitrate and sulfate ion concentrations. During high relative humidity (African dusty days), it is proposed that the mechanism of $\mathrm{NO}_{2}$ hydrolysis predominates whereas during Arabian dusty days, where the air is relatively dry, a synergistic mechanism of adsorption and reaction between $\mathrm{NO}_{2}$

$\mathrm{HONO}$ is an important precursor for $\mathrm{OH}$ radicals in the atmosphere. Compared to ozone and formaldehyde, $\mathrm{HONO}$ photolysis is considered the major source of $\mathrm{OH}$ radicals in the early morning (Finlayson-Pitts and Pitts, 2000). The main source of HONO formation in the troposphere is attributed to the heterogeneous hydrolysis of $\mathrm{NO}_{2}$ on

$\mathrm{NO}_{2}+\mathrm{H}_{2} \mathrm{O} \stackrel{\text { surface }}{\longrightarrow} \mathrm{HONO}_{(\mathrm{g})}+\mathrm{HNO}_{3}$ (particle)

ACPD

14, 4827-4839, 2014

Contribution of

airborne dust

particles to HONO

sources

N. A. Saliba et al.

Title Page

Abstract

Introduction

Conclusions

References

Tables

Figures

14

$>1$

4

Back

Close

Full Screen / Esc

Printer-friendly Version

Interactive Discussion 
This heterogeneous reaction has been studied on several underlying substrates such as soot, glass, mineral oxides and aerosol surfaces (Finlayson-Pitts et al., 2003; Ma et al., 2013; Ullerstam et al., 2003; Underwood et al., 1999, 2001; Yu et al., 2009). In urban regions, the reaction of $\mathrm{NO}_{2}$ on surfaces is well known to be dependent on 5 relative humidity (Finlayson-Pitts et al., 2003) (and references therein) while the reactivity of the surface towards $\mathrm{NO}_{2}$ is a function of other competing reactions such as the reaction of $\mathrm{NO}_{2}$ in the presence of $\mathrm{SO}_{2}$ on mineral surfaces (Liu et al., 2012). As an example, $\mathrm{TiO}_{2}$ nanoparticles which have been used in self-cleaning window glass, building materials, and on roads in Europe, Japan and the USA (Beaumont et al., 2009; 10 Langridge et al., 2009) are considered a source for $\mathrm{HONO}$ and $\mathrm{H}_{2} \mathrm{O}_{2}$ from $\mathrm{NO}_{2}$ and $\mathrm{H}_{2} \mathrm{O}$. $\mathrm{TiO}_{2}$ in dust was also shown to be a contributor to the formation of HONO (Ma et al., 2013; Ndour et al., 2008). Furthermore, modeling studies suggest that mineral aerosols surfaces account for $40 \%$ of nitrate formation and dust events create a favorable medium for the accumulation of nitrates (Dentener et al., 1996; Guo et al., 2011;

Usher et al., 2003). The uptake of $\mathrm{SO}_{2}$ on mineral oxide surfaces was shown to undergo a two-step mechanism including the reversible adsorption of $\mathrm{SO}_{2}$ on the surface followed by the oxidation to sulfate (Ullerstam et al., 2002). In the case where $\mathrm{SO}_{2}$ is co-adsorbed with $\mathrm{NO}_{2}$ on the surface, it is shown that the oxidant is gaseous $\mathrm{NO}_{2}$ which reacts with adsorbed $\mathrm{SO}_{2}$ to produce sulfate in the particle phase. The oxidant role of $\mathrm{NO}_{2}$ leads to nitrate or contributes to the formation of sulfate on the surface (Borerisen et al., 2000; Ma et al., 2013; Phillips, 2013; Wu et al., 2013).

Given the reactivity of mineral oxide surfaces towards $\mathrm{NO}_{2}$ and $\mathrm{SO}_{2}$, some studies reported an increase of HONO levels during dust storms (Phillips, 2013; Wang et al., 2003; Wu et al., 2013; Zhu et al., 2010), however, the mechanism of HONO formation on airborne dust particles is still not understood. This study assesses the increase of HONO in the gas phase during two dust events; Arabian and Saharan, accompanied with aerosols at different relative humidity. Consequently, two mechanisms of actions for the formation of HONO are proposed.
ACPD

$14,4827-4839,2014$

Contribution of

airborne dust

particles to HONO

sources

N. A. Saliba et al.

Title Page

Abstract

Introduction

Conclusions

References

Tables

Figures

14

$\Delta \mathbf{I}$

4

Back

Close

Full Screen / Esc

Printer-friendly Version

Interactive Discussion 


\section{Methods}

\subsection{Collection techniques}

Soluble gases and size resolved aerosols were sampled at ambient level during Arabian and African dusty days. Dusty days were predicted using the NOAA-Hybrid Single

5 Particle Lagrangian Integrated Trajectory Model (HYSPLIT) (Draxler and Rolph, 2014). The aerosol sampling duration extended over $24 \mathrm{~h}$ using Teflon filters housed in Harvard cartridges. Following collection and gravimetric calculation of PM concentrations, the filters are cut into four equal pieces that are frozen until ready for chemical analysis (Kouyoumdjian and Saliba, 2006; Saliba et al., 2009, 2010).

Soluble gases ( $\mathrm{HONO}, \mathrm{HNO}_{3}$ and $\mathrm{H}_{2} \mathrm{SO}_{4}$ ) were sampled using a diffusion denuder system. The system is based on a series of Honey Comb denuders $(\mathrm{HC})$ for sampling trace gases as described in Saliba and Chamseddine (Saliba and Chamseddine, 2012). The aerosol and gas samples are collected using a Rupprecht \& Patashnick Partisol 2300 speciation sampler equipped with ChemComb cartridges in which three Honeycomb $(\mathrm{HC})$ denuders are placed upstream of a pre-weighed Teflon filter that is housed between two Teflon meshes.

\subsection{Ion chromatography}

Two quarters of each Teflon filter are extracted in $10 \mathrm{~mL}$ deionized water and then sonicated for $20 \mathrm{~min}$. Coated denuders are extracted by a $10 \mathrm{~mL}$ of a $0.05 \% \mathrm{H}_{2} \mathrm{O}_{2}$

solution. Both extracts are filtered and analyzed by ion chromatography (Saliba and Chamseddine, 2012).

\section{Results and discussion}

Samples were collected between October 2009 and April 2011. Sampling data were divided into non-dusty and dusty days (Tables S1 and S2). Based on HYSPLIT backward

Contribution of

airborne dust particles to HONO

sources

N. A. Saliba et al.

Title Page

Abstract

Introduction

Conclusions

References

Tables

Figures

14

$>$ I

4

Back

Close

Full Screen / Esc

Printer-friendly Version

Interactive Discussion 
trajectories, two routes for wind were identified: a SE backward wind trajectory originating from Arabian deserts and a SW backward trajectory originating from African deserts.

Gas phase composition: The average gas phase $\mathrm{HCl}, \mathrm{HONO}, \mathrm{HNO}_{3}$, and $\mathrm{H}_{2} \mathrm{SO}_{4}$ 5 (sum of $\mathrm{SO}_{2}$ and $\mathrm{H}_{2} \mathrm{SO}_{4}$ captured by the denuders) levels for the sampling periods are shown in Fig. 1. The average concentrations for $\mathrm{HCl}, \mathrm{HONO}, \mathrm{HNO}_{3}$ and $\mathrm{H}_{2} \mathrm{SO}_{4}$ during non-dusty days were $1.79 \pm 1.11,0.89 \pm 0.33,1.21 \pm 0.69$, and $15.69 \pm 5.74 \mu \mathrm{gm}^{-3}$, respectively. There was a burst of $\mathrm{HCl}, \mathrm{HONO}, \mathrm{HNO}_{3}$ and $\mathrm{H}_{2} \mathrm{SO}_{4}$ during dusty days. In the present set of data, a twofold and a threefold increase of HONO levels was 10 observed during African and Arabian dust storms, respectively. The increase in the acidic gas concentration was accompanied by an increase in the PM ions concentration (Fig. 2).

During African dust storms, the relative humidity was high (average $\mathrm{RH} \sim 75 \%$ ). Water molecules form multilayer water films on urban surfaces including particles (Moussa 15 et al., 2009; Sumner et al., 2004). The presence of water on the surface acts as a shield preventing the interaction of $\mathrm{NO}_{2}$ and $\mathrm{SO}_{2}$ directly with the active sites on the particle surface. This is confirmed by the correlation between gaseous $\mathrm{HONO}$ and $\mathrm{HNO}_{3}$ $(R=0.52)$ which is enhanced in the Fall and Winter seasons to become 0.94 (Fig. S1). Also, the correlation between $\mathrm{NO}_{3}^{-}$(particle) and HONO (gas) $(R=1.00)$ during the 20 Fall-Winter season suggests that the heterogeneous hydrolysis of $\mathrm{NO}_{2}$ on dust particles is the main mechanism for gas phase HONO formation during those episodes. $\mathrm{SO}_{2}$ reacts with surface water through several steps to form $\mathrm{H}_{2} \mathrm{SO}_{4}$ which is taken up by the particle phase as $\mathrm{SO}_{4}^{2-}$. This conclusion is confirmed by the positive correlation (0.92) between gas phase HONO and particle sulfate. The noticed higher con25 centration for HONO in Spring-Summer $\left(2.2 \mathrm{\mu g} \mathrm{m}^{-3}\right)$ relative to the Fall-winter season $\left(1.9 \mathrm{\mu g} \mathrm{m}^{-3}\right)$ suggests an additional photochemical source for HONO due to secondary organic aerosols formation during summer (Broske et al., 2003; George et al., 2005).

The mechanism of $\mathrm{NO}_{2}$ hydrolysis via the dimerization of $\mathrm{NO}_{2}$ into $\mathrm{N}_{2} \mathrm{O}_{4}$ (Reactions $\mathrm{R} 2$ and $\mathrm{R} 3$ ) and the formation of $\mathrm{NO}^{+} \mathrm{NO}_{3}^{-}$intermediate (Reaction R4) as sug-

\section{ACPD}

14, 4827-4839, 2014

Contribution of

airborne dust

particles to HONO

sources

N. A. Saliba et al.

Title Page

Abstract

Introduction

Conclusions

References

Tables

Figures

14

$>1$

4

Back

Close

Full Screen / Esc

Printer-friendly Version

Interactive Discussion 
gested by Finlayson-Pitts and coworkers on water surfaces is proposed (FinlaysonPitts et al., 2003). The final products are thus $\mathrm{HONO}_{(\mathrm{g})}$ and $\mathrm{HNO}_{3 \text { (particle) }}$ as illustrated in Reaction (R5).

$$
2 \mathrm{NO}_{2(\mathrm{~g})} \leftrightarrow \mathrm{N}_{2} \mathrm{O}_{4(\mathrm{~g})}
$$$$
5 \quad \mathrm{~N}_{2} \mathrm{O}_{4(\mathrm{~g})} \leftrightarrow \mathrm{N}_{2} \mathrm{O}_{4} \text { (surface) }
$$

$\mathrm{N}_{2} \mathrm{O}_{4 \text { (surface) }} \rightarrow \mathrm{ONONO}_{2 \text { (surface) }} \rightarrow \mathrm{NO}^{+} \mathrm{NO}_{3 \text { (surface) }}^{-}$

$\mathrm{NO}^{+} \mathrm{NO}_{3}^{-} \stackrel{\mathrm{H}_{2} \mathrm{O}}{\longrightarrow} \mathrm{HONO}_{(\mathrm{g})}+\mathrm{H}^{+}+\mathrm{NO}_{3}^{-}$

On the contrary, during Arabian dust storms, where the air is relatively dry (average $\mathrm{RH} \sim 30 \%)$, there was a poor correlation for $\mathrm{HONO}_{(\mathrm{g})}$ with $\mathrm{HNO}_{3(\mathrm{~g})}(R=0.05)$ and with $\mathrm{HONO}_{(\mathrm{g})}$ and particulate nitrate $(R=0.01)$ suggesting that Reaction (R1) is not the main source for HONO formation. On the other hand, gas phase HONO was highly correlated with gas phase $\mathrm{H}_{2} \mathrm{SO}_{4}(R=0.74)$ (Fig. S2), additionally, during the FallWinter seasons, there is a strong correlation between particle phase nitrates and sulfates $(R=0.96)$ and during the Spring-Summer seasons, sulfate is highly correlated 5 with $\mathrm{H}_{2} \mathrm{SO}_{4}(R=0.92), \mathrm{HNO}_{3(\mathrm{~g})}(R=0.67)$ and $\mathrm{HONO}_{(\mathrm{g})}(R=0.95)$. These correlations suggest that there is a synergistic mechanism of adsorption and reaction between $\mathrm{NO}_{2}$ and $\mathrm{SO}_{2}$ on dust particles; mainly mineral oxides.

Hydroxyl M-OH groups on oxide surfaces react with acidic molecules such as $\mathrm{NO}_{2}$ and $\mathrm{SO}_{2}$ via a nucleophilic attack of the oxygen atom to form adsorbed sulfite $\left(\mathrm{M}-\mathrm{SO}_{3}\right)$ and nitrate $\left(\mathrm{M}-\mathrm{NO}_{3}\right)$, respectively (Ma et al., 2008; Tsyganenko et al., 2000). When both $\mathrm{NO}_{2}$ and $\mathrm{SO}_{2}$ are available, $\mathrm{SO}_{2}$ competes with $\mathrm{NO}_{2}$ for the same adsorption sites, and adsorbs more strongly (Ling et al., 2013; Liu et al., 2012; Prades et al., 2009, 2007; Rodriguez et al., 2000). Hence, only a minor amount of $\mathrm{NO}_{2}$ chemisorbs on the surface to form $\mathrm{M}-\mathrm{ONO}_{2}$ which can proceed to form adsorbed $\mathrm{NO}_{3}^{-}$via Reaction (R6).
ACPD

14, 4827-4839, 2014

\section{Contribution of \\ airborne dust particles to HONO \\ sources}

N. A. Saliba et al.

\section{Title Page}

Abstract

Introduction

Conclusions

References

Tables

Figures

14

-1

4

Back

Close

Full Screen / Esc

Printer-friendly Version

Interactive Discussion of $\mathrm{NO}_{2}$ dimerizes into $\mathrm{N}_{2} \mathrm{O}_{4}$ which form a physisorbed layer on the surface. The coadsorption of $\mathrm{SO}_{2}$ and the oxidant $\mathrm{N}_{2} \mathrm{O}_{4}$ lead to the formation of $\mathrm{H}_{2} \mathrm{SO}_{4}$ and $\mathrm{HONO}$ in 
the gas phase (Reaction R8). Such effect has been shown to exist. For instance, Ma et al. (2008) (Ma et al., 2008) showed that adsorption of $\mathrm{NO}_{2}$ on alumina was altered in the presence of $\mathrm{SO}_{2}$. In similar studies, co-adsorption of $\mathrm{SO}_{2}$ and $\mathrm{NO}_{2}$ showed that the intermediate $\mathrm{N}_{2} \mathrm{O}_{4}$ leads to nitrates and sulfates in pathways different than 5 the formation of $\mathrm{NO}^{+} \mathrm{NO}_{3}^{-}$on the surface (Liu et al., 2012). In this proposed model, a competition for $\mathrm{NO}_{2}$, between surface adsorption forming nitrate, and its acting as an oxidant, forming sulfate is suggested. Products conform with field measurements of poor correlation between gas phase $\mathrm{HONO}$ and gas and particulate phases of nitrates and high correlation between gas phase HONO and gas and particle phase of sulfate.

10 Furthermore, the higher concentration of sulfates in particles during Arabian desert episodes lead us to suggest that the presence of $\mathrm{SO}_{2}$ on the surface reduces the formation of surface nitrate species while enhancing the formation of surface sulfate.

$\mathrm{NO}_{2(\mathrm{~g})}+\mathrm{MOH} \rightarrow \mathrm{HNO}_{3 \text { (particle) }}+\mathrm{M}$

$\mathrm{SO}_{2 \text { (ads) }}+\mathrm{MOH} \rightarrow \mathrm{M}-\mathrm{SO}_{3 \text { (ads) }}+\mathrm{H}^{+}$

15

$$
\mathrm{M}-\mathrm{SO}_{3(\text { ads })}+\mathrm{N}_{2} \mathrm{O}_{4(\mathrm{~g})}+\mathrm{H}_{2} \mathrm{O} \rightarrow \mathrm{SO}_{4(\text { particle })}^{2-}+2 \mathrm{HONO}_{(\mathrm{g})}+\mathrm{M}
$$

The enhanced formation of surface sulfate is an important characteristic since it changes the physical properties of the mineral dust particle. A particle coated with sulfate is hygroscopic and will take up water; it may therefore take up more $\mathrm{SO}_{2}$ into this aqueous layer that would otherwise be formed (Zhang and Chan, 2002). Hence,

than suggested by the reactive uptake studies alone (Ullerstam et al., 2003).

The missing source of HONO has several implications on the $\mathrm{OH}$ concentration and oxidative budget in the atmosphere. Furthermore, the simultaneous enhanced formation of sulfates in particles impacts their optical and physical properties. Uptake coefficients and rate constants of the proposed reactions can be further developed in laboratory studies so that proposed reactions are incorporated into regional and global models.
ACPD

14, 4827-4839, 2014

Contribution of

airborne dust

particles to HONO

sources

N. A. Saliba et al.

Title Page

Abstract

Introduction

Conclusions

Tables

References

Figures

14

$>1$

4

Back

Close

Full Screen / Esc

Printer-friendly Version

Interactive Discussion 


\section{Supplementary material related to this article is available online at http://www.atmos-chem-phys-discuss.net/14/4827/2014/ acpd-14-4827-2014-supplement.pdf.}

Acknowledgements. This work has been supported by the Lebanese National Council for Scientific Research and by the American University Research Board (URB) at AUB. The authors gratefully acknowledge the NOAA Air Resources Laboratory (ARL) for the provision of the HYSPLIT transport and dispersion model and/or READY website (http://ready.arl.noaa.gov) used in this publication.

\section{References}

Beaumont, S. K., Gustafsson, R. J., and Lambert, R. M.: Heterogeneous photochemistry relevant to the troposphere: $\mathrm{H}_{2} \mathrm{O}_{2}$ production during the photochemical reduction of $\mathrm{NO}_{2}$ to HONO on UV-illuminated $\mathrm{TiO}_{2}$ surfaces, Chem. Phys. Phys. Chem., 10, 331-333, 2009.

Borerisen, C., Kitether, U., Schear, V., Vogt, R., and Zellner, R.: Mechanism and kinetics of the reactions of $\mathrm{NO}_{2}$ or $\mathrm{HNO}_{3}$ with alumina as a mineral dust model compound, J. Phys. Chem.

Bröske, R., Kleffmann, J., and Wiesen, P.: Heterogeneous conversion of $\mathrm{NO}_{2}$ on secondary organic aerosol surfaces: A possible source of nitrous acid (HONO) in the atmosphere?, Atmos. Chem. Phys., 3, 469-474, doi:10.5194/acp-3-469-2003, 2003.

Dentener, F. J., Carmichael, G. R., Zhang, Y., Lelieveld, J., and Crutzen, P. J.: Role of mineral aerosol as a reactive surface in the global troposphere, J. Geophys. Res.-Atmos., 101, 22869-22889, 1996.

Draxler, R. R. and Rolph, G. D.: HYSPLIT (HYbrid Single-Particle Lagrangian Integrated Trajectory) Model access via NOAA ARL READY Website, available at: http://www.arl.noaa.gov/ HYSPLIT.php (last access: February 2014), NOAA Air Resources Laboratory, College Park, MD, 2013.

Finlayson-Pitts, B. J. and Pitts, J. N.: Chemistry of the Upper and Lower Atmosphere: Theory, Experiments and Applications, Academic Press, San Diego, CA, 2000.

\section{ACPD}

Contribution of

airborne dust particles to HONO

sources

N. A. Saliba et al.

\section{Title Page}

Abstract

Conclusions

Tables

14

4

Back
Introduction

References
$>1$

Close
Full Screen / Esc

Printer-friendly Version

Interactive Discussion 
Finlayson-Pitts, B. J., Wingen, L., Sumner, A. L., Syomin, D., and Ramazan, K. A.: The heterogeneous hydrolysis of $\mathrm{NO}_{2}$ in laboratory systems and in outdoor and indoor atmospheres: an integrated mechanism, Phys. Chem. Chem. Phys., 5, 223-242, 2003.

George, C., Strekowski, R. S., Kleffmann, J., Stemmler, K., and Ammann, M.: Photoenhanced 5 uptake of gaseous $\mathrm{NO}_{2}$ on solid organic compounds: a photochemical source of HONO?, Faraday Discuss., 130, 195-210, 2005.

Guo, Y. T., Zhang, J., Wang, S. G., She, F., and Li, X.: Long-term characterization of major water-soluble inorganic ions in $\mathrm{PM}_{10}$ in coastal site on the Japan Sea, J. Atmos. Chem., 68, 299-316, 2011.

10 Kouyoumdjian, H. and Saliba, N. A.: Mass concentration and ion composition of coarse and fine particles in an urban area in Beirut: effect of calcium carbonate on the absorption of nitric and sulfuric acids and the depletion of chloride, Atmos. Chem. Phys., 6, 1865-1877, doi:10.5194/acp-6-1865-2006, 2006.

Langridge, J. M., Gustafsson, R. J., Griffiths, P. T., Anthony Cox, R., Lambert, R. M., and 15 Jones, R. L.: Solar driven nitrous acid formation on building material surfaces containing titanium dioxide: a concern for air quality in urban areas?, Atmos. Environ., 43, 5128-5131, 2009.

Ling, L., Han, P., Wang, B., and Zhang, R.: DFT study on the regeneration mechanism of ZnO surface during the desulfurization of $\mathrm{H}_{2} \mathrm{~S}$, Fuel Process. Technol., 109, 49-56, 2013.

20

Liu, C., Ma, Q., Liu, Y. C., Ma, J., and He, H.: Synergistic reaction between $\mathrm{SO}_{2}$ and $\mathrm{NO}_{2}$ on mineral oxides: a potential formation pathway of sulfate aerosol, Phys. Chem. Chem. Phys., 14, 1668-1676, 2012.

Ma, J., Liu, Y. C., Han, C., Ma, Q., Liu, C., and He, H.: Review of heterogeneous photochemical reactions of $\mathrm{NO}_{y}$ on aerosol - a possible daytime source of nitrous acid (HONO) in the atmosphere, J. Environ. Sci., 25, 326-334, 2013.

$\mathrm{Ma}, \mathrm{Q}$., Liu, Y. C., and $\mathrm{He}, \mathrm{H}$.: Synergistic effect between $\mathrm{NO}_{2}$ and $\mathrm{SO}_{2}$ in their adsorption and reaction on $\gamma$-alumina, J. Phys. Chem. A, 112, 6630-6635, 2008.

Moussa, S. G., McIntire, T. M., Szori, M., Roeselova, M., Tobias, D. J., Grimm, R. L., Hemminger, J. C., and Finlayson-Pitts, B. J.: Experimental and theoretical characterization of atmospherically relevant surfaces, J. Phys. Chem. A, 113, 2060-2069, 2009.

ACPD

14, 4827-4839, 2014

Contribution of

airborne dust

particles to HONO

sources

N. A. Saliba et al.

Title Page

Abstract

Introduction

Conclusions

References

Tables

Figures

14

-1

4

Back

$>$

Close

Full Screen / Esc

Printer-friendly Version

Interactive Discussion 
Ndour, M., D’Anna, B., George, C., Ka, O., Balkanski, Y., Kleffmann, J., Stemmler, K., and Ammann, M.: Photoenhanced uptake of $\mathrm{NO}_{2}$ on mineral dust: laboratory experiments and model simulations, Geophys. Res. Lett., 35, L05812, doi:10.1029/2007GL032006, 2008.

Phillips, L. F.: Atmospheric reactions on electrically charged surfaces, Phys. Chem. Chem. Phys., 15, 10749-10752, 2013.

Prades, J. D., Cirera, A., and Morante, J. R.: First-principles study of $\mathrm{NO}_{\mathrm{x}}$ and $\mathrm{SO}_{2}$ adsorption onto $\mathrm{SnO}_{2}$ (110), J. Electrochem. Soc., 154, 675-680, 2007.

Prades, J. D., Cirera, A., and Morante, J. R.: Ab initio calculations of $\mathrm{NO}_{2}$ and $\mathrm{SO}_{2}$ chemisorption onto non-polar ZnO surfaces, Sensor. Actuat. B-Chem., 142, 179-184, 2009.

10 Prades, J. D., Cirera, A., Morante, J. R., Pruneda, J. M., and Ordejon, P.: Ab initio study of $\mathrm{NO}_{\mathrm{x}}$ compounds absorption on $\mathrm{SnO}_{2}$ surface, E-MRS Symposium: $\mathrm{G}$ - Functional Materials for Micro and Nano Systems, Switzerland, Strasbourg, France, 2006.

Rodriguez, J. A., Jirsak, T., Dvorak, J., Sambasivan, S., and Fischer, D.: Reaction of $\mathrm{NO}_{2}$ with $\mathrm{Zn}$ and $\mathrm{ZnO}$ : photoemission, XANES, and density functional studies on the formation of $\mathrm{NO}_{3}$, J. Phys. Chem. B, 104, 319-328, 2000.

Rolph, G. D.: Real-time Environmental Applications and Display sYstem (READY) Website, available at: http://www.ready.noaa.gov (last access: February 2014), NOAA Air Resources Laboratory, College Park, MD, 2013.

Saliba, N. A. and Chamseddine, A.: Uptake of acid pollutants by mineral dust and their effect on aerosol solubility, Atmos. Environ., 46, 256-263, 2012.

Saliba, N. A., Atallah, M., and Al-Kadamany, G.: Levels and indoor-outdoor relationships of $\mathrm{PM}_{10}$ and soluble inorganic ions in Beirut, Lebanon, Atmos. Res., 92, 131-137, 2009.

Saliba, N. A., El Jam, F., El Tayar, G., Obeid, W., and Roumié, M.: Origin and variability of particulate matter $\left(\mathrm{PM}_{10}\right.$ and $\left.\mathrm{PM}_{2.5}\right)$ mass concentrations over an Eastern Mediterranean city, Atmos. Res., 97, 106-114, 2010.

Sumner, A. L., Menke, E. J., Dubowski, Y., Newberg, J. T., Penner, R. M., Hemminger, J. C., Wingen, L., Brauers, T., and Finlayson-Pitts, B. J.: The nature of water on surfaces of laboratory systems and implications for heterogeneous chemistry in the troposphere, Phys. Chem. Chem. Phys., 6, 604-613, 2004.

so Tsyganenko, A. A., Storozheva, E. N., Manoilova, O. V., Lesage, T., Daturi, M., and Lavalley, J.C.: Brønsted acidity of silica silanol groups induced by adsorption of acids, Catal. Lett., 70, 159-163, 2000.
ACPD

14, 4827-4839, 2014

Contribution of

airborne dust

particles to HONO

sources

N. A. Saliba et al.

Title Page

Abstract

Introduction

Conclusions

References

Tables

Figures

14

$\Delta \mathbf{I}$

4

Back

Close

Full Screen / Esc

Printer-friendly Version

Interactive Discussion 
Ullerstam, M., Vogt, R., Langer, S., and Ljungstrom, E.: The kinetics and mechanism of $\mathrm{SO}_{2}$ oxidation by $\mathrm{O}_{3}$ on mineral dust, Phys. Chem. Chem. Phys., 4, 4694-4699, 2002.

Ullerstam, M., Johnson, M. S., Vogt, R., and Ljungström, E.: DRIFTS and Knudsen cell study of the heterogeneous reactivity of $\mathrm{SO}_{2}$ and $\mathrm{NO}_{2}$ on mineral dust, Atmos. Chem. Phys., 3, 5 2043-2051, doi:10.5194/acp-3-2043-2003, 2003.

Underwood, G. M., Miller, T. M., and Grassian, V. H.: Transmission FT-IR and Knudsen cell study of the heterogeneous reactivity of gaseous nitrogen dioxide on mineral oxide particles, J. Phys. Chem. A, 103, 6184-6190, 1999.

Underwood, G. M., Song, C. H., Phadnis, M., Carmichael, G. R., and Grassian, V. H.: heterogenous reactions of $\mathrm{NO}_{2}$ and $\mathrm{HNO}_{3}$ on oxides and mineral dust: a combined laboratory and modeling study, J. Geophys. Res., 106, 18055-18066, 2001.

Usher, C. R., Michel, A. E., and Grassian, V. H.: Reactions on mineral dust, Chem. Rev., 103, 4883-4939, 2003.

Wang, S. G., Ackermann, R., Spicer, C. W., Fast, J. D., Schmeling, M., and Stutz, J.: Atmospheric observations of enhanced $\mathrm{NO}_{2}-\mathrm{HONO}$ conversion on mineral dust particles, Geophys. Res. Lett., 30, 1595, doi:10.1029/2003GL017014, 2003.

Wu, F. C., Xie, P. H., Li, A., Chan, K. L., Hartl, A., Wang, Y., Si, F. Q., Zeng, Y., Qin, M., Xu, J., Liu, J. G., Liu, W. Q., and Wenig, M.: Observations of $\mathrm{SO}_{2}$ and $\mathrm{NO}_{2}$ by mobile DOAS in the Guangzhou eastern area during the Asian Games 2010, Atmos. Meas. Tech., 6, 2277-2292, doi:10.5194/amt-6-2277-2013, 2013.

Yu, Y., Galle, B., Panday, A., Hodson, E., Prinn, R., and Wang, S.: Observations of high rates of $\mathrm{NO}_{2}-\mathrm{HONO}$ conversion in the nocturnal atmospheric boundary layer in Kathmandu, Nepal, Atmos. Chem. Phys., 9, 6401-6415, doi:10.5194/acp-9-6401-2009, 2009.

Zhang, Y. H. and Chan, C. K.: Understanding the hygroscopic properties of supersaturated droplets of metal and ammonium sulfate solutions using Raman spectroscopy, J. Phys. Chem. A, 106, 285-292, 2002.

Zhu, S., Butler, T., Sander, R., Ma, J., and Lawrence, M. G.: Impact of dust on tropospheric chemistry over polluted regions: a case study of the Beijing megacity, Atmos. Chem. Phys., 10, 3855-3873, doi:10.5194/acp-10-3855-2010, 2010.

\section{ACPD}

$14,4827-4839,2014$

Contribution of

airborne dust

particles to HONO

sources

N. A. Saliba et al.

Title Page

Abstract

Introduction

Conclusions

References

Tables

Figures

14

$\Delta \mathbf{I}$

4

Back

Close

Full Screen / Esc

Printer-friendly Version

Interactive Discussion 


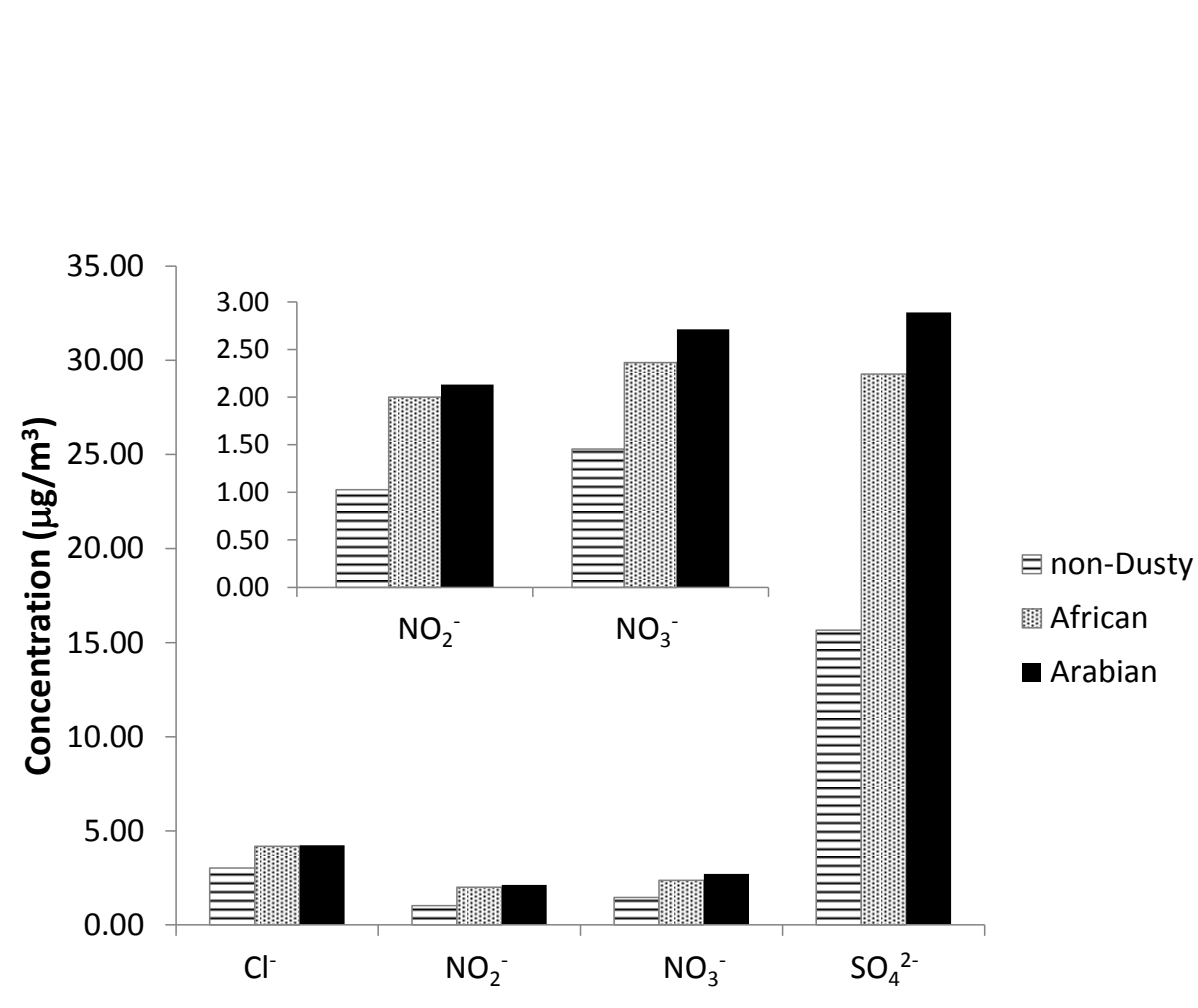

ACPD

14, 4827-4839, 2014

\section{Contribution of airborne dust particles to HONO sources}

N. A. Saliba et al.

\section{Title Page}

Abstract

Conclusions

\section{Tables}

14

4

Back

Fig. 1. Average concentration of ions corresponding to gases measured during the sampling period in the presence and absence of dust episodes. The inset expands the y-axis around nitric acid and HONO concentrations.

\section{Full Screen / Esc}

Printer-friendly Version

Interactive Discussion 


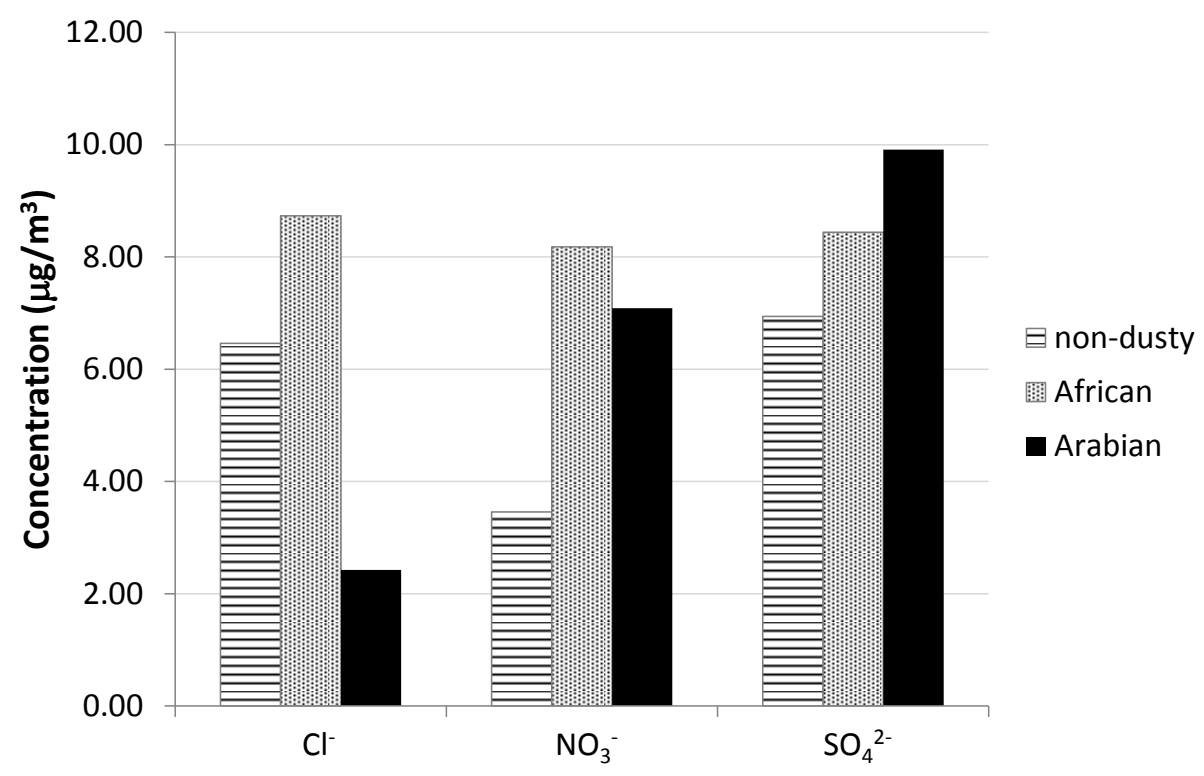

Fig. 2. Average concentration of particle phase chloride, nitrate and sulfate measured during the sampling period in the presence and absence of dust episodes.

\section{ACPD}

14, 4827-4839, 2014

\section{Contribution of airborne dust particles to HONO sources}

N. A. Saliba et al.

\section{Title Page}

\section{Abstract}

Conclusions

Tables

14

Back

Full Screen / Esc

Printer-friendly Version 